\title{
The relationship between I-131 uptake in postoperative residue thyroid tissue and absorbed doses calculated with MIRDOSE3 and pre-ablation thyroglobulin levels in patients with differential thyroid cancer: A retrospective comparison study
}

\section{Diferansiye tiroid kanserli hastalarda postoperatif} rezidüel tiroid dokusundaki l-131 tutulumu, MIRDOSE3 ile hesaplanan absorbe dozlar ve ablasyon öncesi tiroglobulin seviyeleri arasındaki ilişki: Bir retrospektif karşılaştırma çalışması

Fadime Demirr ${ }^{1}$, Zekiye Hasbek ${ }^{2}$, Taner Erselcan ${ }^{3}$, Büllent Turgut ${ }^{2}$

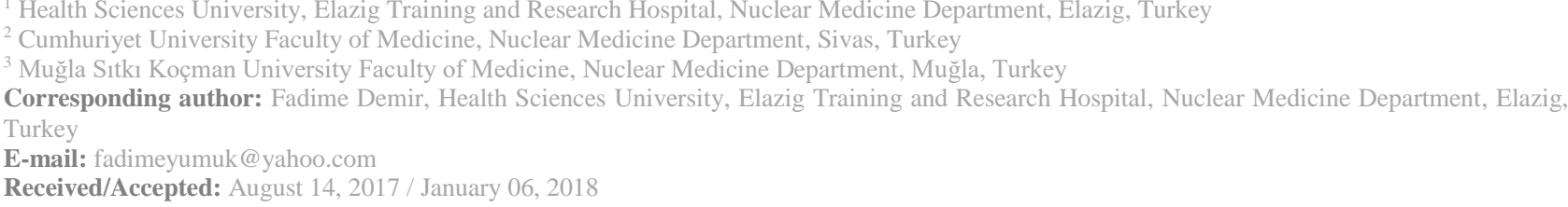

\section{SUMMARY}

Objective: The aim of this study was to compare I-131 uptake in postoperative residue thyroid tissue and absorbed doses calculated with MIRDOSE3 and pre-ablation thyroglobulin levels in patients with differential thyroid cancer and was to investigate whether there is a relationship in terms of effectiveness to treatment efficacy.

Method: Seventy-four patients were included in the study. Serum thyroglobulin and thyroid stimulating hormone levels before ablation were measured in patients. Uptake values were calculated using I-131 whole body scan scintigraphy images taken on the 8th day after ablation. The findings were evaluated with low dose I-131 whole body scan scintigraphy at 8th-12th months after ablation. Also the effective half-life of I-131, cumulative activity and I-131 residence time were calculated for each patient. The values found were used in the MIRDOSE3 program to calculate total body absorptive doses and comparison was made between the parameters.

Results: Thyroglobulin values and uptake values were compared with sperman analysis. There was intermediate correlation between them $(\mathrm{r}=0.616, \mathrm{p}=0.01)$. There was a low correlation in the negative direction between thyroid stimulating hormone levels and uptake values of patients before ablation $(\mathrm{r}=-0.218, \mathrm{p}=0.05)$. In 74 patients 8th-12th. Month whole body scan scintigraphy and thyroglobulin results are evaluated; $3(4.1 \%)$ patients were not complete ablated and 71 patients (95.9\%) were complete ablated. There was a significant difference only in the thyroglobulin value between complete ablated and non-ablated patient groups $(\mathrm{p}=0.001)$. There was a low correlation between absorbed doses and thyroglobulin values $(r=0.212, \mathrm{p}=0.05)$.

Conclusions: As a result, we observed that thyroglobulin values measured before I-131 treatment inform about residual tissue after surgery and residual tissue size may affect treatment efficacy. We also think that attention should be paid to 
the treatment and follow-up protocol in terms of complete ablation success in patients with high pre-treatment thyroglobulin values.

Keywords: I-131, thyroglobulin, thyroid cancer.

\section{ÖZET}

Amaç: Bu çalışmadaki amacımız, I-131 ablasyon tedavisi uygulanan diferansiye tiroid kanserli hastalarda, ablasyon öncesi ölçülen serum tiroglobulin değerleri ile ablasyon sonrası rezidü tiroid dokudaki I-131 uptake değerleri ve MIRDOSE3 ile hesaplanan absorbe dozları karşılaştırarak, aralarında rezidü doku miktarı tahmini ve tedavi etkinliğine etkileri açısından bir ilişki olup olmadığını araştırmaktır.

Yöntem: Çalışmaya yetmiş dört hasta dâhil edildi. Hastalarda ablasyon öncesi serum tiroglobulin ve tiroid stimülan hormon düzeyleri ölçüldü. Ablasyon sonrası 8. gün I-131 tüm vücut tarama sintigrafi görüntüleri de kullanılarak uptake değerleri hesapland1. Bulgular ablasyon sonrası 8.-12. ayda yapılan düşük doz I-131 ile tüm vücut tarama sintigrafi görüntüleri ile birlikte değerlendirildi. Ayrıca her hastada I-131'in efektif yarı ömrü, kümülatif aktivite ve I-131 kalım süresi hesapland1. Bulunan değerler MIRDOSE3 programında kullanılarak total vücut absorbe dozlar hesapland1 ve parametreler arası karşılaştırılma yapıldı.

Bulgular: Hastalarda; tiroglobulin değerleri ile uptake değerleri sperman analizi ile karşılaştırıldığında, aralarında orta düzeyde korelasyon bulundu ( $\mathrm{r}=0.616, \mathrm{p}=0.01)$. Hastaların ablasyon öncesi tiroid stimülan hormon düzeyleri ile uptake değerleri karșılaștırıldığında, aralarında negatif yönde düșük düzeyde korelasyon bulundu $(r=-0.218, p=0.05)$. Yetmiș dört hastanın 8.-12. ay tüm vücut tarama sintigrafileri ve tiroglobulin sonuçları değerlendirildiğinde, $3(\% 4,1)$ hastada tam ablasyon yokken, $71(\% 95,9)$ hastada tam ablasyon vardı. Tam ablasyon sağlanamayan hastaların tedavi öncesindeki tiroglobulin düzeyleri tam ablasyon sağlananlara göre istatistiksel olarak anlamlı düzeyde yüksek bulundu $(p=0.001)$. Absorbe dozlar ile tiroglobulin değerleri karşılaştırıldığında, aralarında düşük düzeyde korelasyon bulundu $(\mathrm{r}=0.212, \mathrm{p}=0.05)$.

Sonuç: Sonuç olarak, I-131 ablasyon tedavisi öncesinde ölçülen tiroglobulin değerlerinin cerrahi sonrası kalan doku hakkında bilgi verebileceğini ve kalan doku boyutunun da tedavi etkinliğini etkileyebileceğini gözlemledik. Ayrıca tedavi öncesi tiroglobulin değerleri yüksek olan hastalarda tam ablasyon başarısı açısından tedavi ve takip protokolüne dikkat edilmesi gerektiğini düşünüyoruz.

Anahtar sözcükler: I-131, tiroglobulin, tiroid kanseri.

\section{INTRODUCTION}

Thyroid cancers constitute $1-2 \%$ of the all malignancies. The incidence of thyroid cancer varies among regions. But it increases all around the world ${ }^{1}$. Papillary and follicular cancers are referred under the title of differentiated thyroid cancer (DTC). If the diagnosis is at the early stage; it is commonly treatable, with good prognosis and has long life expectancy ${ }^{2}$. Papillary carcinoma constitutes $70-80 \%$ of DTC. Male / female ratio is $3 / 1$ for papillary carcinoma, $2 / 1$ for follicular carcinoma as well ${ }^{1}$. Therapy with I-131 (radioiodine therapy) and suppression with thyroid hormone are treatment protocol administered as a routine in many centers in patients with total/near total thyroidectomy in order to ablate the residual tissue and to follow-up by serum thyroglobulin $(\mathrm{Tg})$ level $^{3,}{ }^{4}$. In most DTC patients, good prognosis is seen owing to early diagnosis and by means of classical surgery, radioiodine therapy and $\mathrm{TSH}$ suppression at the rate of $91 \%$, survival for 20 years is observed ${ }^{5}$.

I-131 uptake in thyroid bed can be influenced by several factors, including TSH levels, presence of remnant tissue masse, malignancy grade and the (rare) co-existence of distant metastases with high
I-131 uptake, which significantly decreases the amount of available I-131 in the blood ${ }^{6}$. At a low rate, DTC's can be differentiated and recurrence can be observed ${ }^{7}$. Hence, in differentiated thyroid cancers the follow-up right after the first line treatment is quite vital. $\mathrm{Tg}$ is a glycoprotein generated by only follicular cells of thyroid. Thus, Tg is used as the tumor marker during the followup in post ablation DTC patients ${ }^{6}$. The fact that, Tg levels and I-131 whole body scan (WBS) are used in company is the most precious test during follow-up ${ }^{8}$. In patients with total thyroidectomy followed by I-131 ablation for DTC, the baseline stimulated-Tg level is a good predictor of successful ablation ${ }^{9}$. The absorbed radiation dose is determined by the total amount of radiation energy deposited in the tissue. In Medical International Radiation Dose (MIRD) method the dose absorbed in the target organs are estimated by the activities accumulated in the source organ 10 .

The aim of this study was to compare I-131 uptake in postoperative residue thyroid tissue and absorbed doses calculated with MIRDOSE3 and pre-ablation thyroglobulin levels in patients with differential thyroid cancer. Our other goal was to investigate whether these parameters were a factor 
affecting the success of high dose I-131 ablation therapy.

\section{MATERIAL AND METHODS}

Seventy-four patients who received high-dose I131 therapy with DTC between 2003 and 2011 at the Department of Nuclear Medicine, Cumhuriyet University Medical Faculty were included for this retrospective study. Patients with anti-tg positive and without 8-12th month WBS were excluded from the study. Serum Tg, Anti-Tg and TSH values of pre-ablation and pre-WBS were recorded for all patients. Radioiodine therapy was administered orally in the form of solution or capsule using empirical dose application, and the mean I-131 dose was $111 \pm 13 \mathrm{mCi}$ (100$150 \mathrm{mCi})$.

Thyroid tissue uptake values in thyroid bed were calculated by lining regions of interest (ROI), activity counts obtained from prepared standards and applied total I-131 doses. Thyroidal I-131 uptakes were calculated by scintigraphic techniques with a gamma camera. In the supine position, scintigraphic images were obtained with the use of a single-head gamma camera (Toshiba GCA-7100A) that was equipped with a "high energy parallel hole collimator" and interfaced to a dedicated computer. For image acquisition, a peak energy setting at $364 \mathrm{keV}$ with a $20 \%$ window was used.

Initially; a point source was prepared as a "standard activity" with I-131 and a scintigraphic image of standard was obtained for 1 minute (with use of the same gamma camera, the same acquisition parameters and same ROI placements). Thyroid activity was calculated from obtained counts with the following formula:

Thyroid activity $=($ Point source activity / Point source count) $x$ Thyroid counts

Activity counts from thyroid and background localizations were calculated according to regions of interest (ROIs). Average counts per pixel of ROIs placed over the thyroid localization and ROIs placed over the background area in anterior static images were used for calculating thyroidal uptake of I-131. All ROI placements were done by the same person.

Thyroidal uptake was calculated as "\%" with the following formula;

Thyroid uptake $(\%)=($ Thyroid activity $/$ Total activity given to patient) $\mathrm{x} 100$

Following the administration of I-131 therapy, the amount of radiation on the patients was measured at 2nd, 24th and 48th hours using the Geiger Müller counter at 1 meter and then the effective half-life of 131I was calculated in all patients. Therefore, 10 different standard I-131 activities were prepared and measured from 1 meter distance with Geiger- Müller counter. The averages of doses and dose rates of standard activities were taken into account. The 2nd, 24th and 48th hours radiation (activity) quantity on patients were calculated by using these values and linear regression results. Effective half-lives (Te), cumulative activity and I-131 residence time values were calculated for all patients. The values found were used in the MIRDOSE3 program to calculate total body absorptive doses (TBAD) and compared to other data's.

\section{STATISTICAL ANALYSIS}

The demographic data of all patients and serum $\mathrm{Tg}$, Anti-Tg and TSH levels and calculated thyroid tissue uptake values in thyroid bed obtained from scintigraphic images and total body radiation absorbed doses (TBAD) calculated with MIRDOSE3 program were expressed as average \pm standard deviation. The patient data and statistical analysis were evaluated by using the SPSS 14.0 for Windows Statistical Program (SPSS Inc., Chicago, Illinois, USA). Because the parameters did not show homogeneous distribution, Spearman Test was used to analyze whether there was a correlation between serums $\mathrm{Tg}$, Anti-Tg, TSH levels and thyroid tissue uptake values in thyroid bed and total body radiation absorbed doses. And Mann-Whitney U test was used to determine whether there was a significant difference in these parameters averages between patient group with complete ablation and patient group not complete ablation. A p value less than 0.05 was accepted as statistically significant.

\section{RESULTS}

$62(84 \%)$ women and $12(16 \%)$ male 74 patients aged between 19 and 74 years (mean age: $48.5 \pm$ 13.5) were included in the study. $30(40.5 \%)$ of the patients were below the age of 45 , and 44 $(59.5 \%)$ were 45 years or older. According to pathology results, $64(86.5 \%)$ of them were papillary Ca. $3(4.1 \%)$ of them were follicular $\mathrm{Ca}$, $7(9.5 \%)$ of them were well differentiated thyroid tumor of unknown malignant.

In 74 patients 8th-12th Month WBS and $\mathrm{Tg}$ results are evaluated; $3(4.1 \%)$ patients were not complete ablated and 71 patients $(95.9 \%)$ were complete ablated.

The mean values of all parameters in the two groups are as in Table 1. 
Table 1. TSH, Tg, Te and Absorbed Dose Calculated with MIRDOSE3 in patients with complete ablation and without complete ablation.

$\begin{array}{cclll}\begin{array}{c}\text { Serum TSH } \\ (\mu \mathrm{IU} / \mathrm{mL})\end{array} & \begin{array}{c}\text { Serum Tg } \\ (\mathrm{ng} / \mathrm{ml})\end{array} & \begin{array}{l}\text { T(Effective Half Life) } \\ (\text { hour })\end{array} & \begin{array}{l}\text { Thyroidal } \\ \text { Uptake }(\%)\end{array} & \begin{array}{l}\text { TBAD } \\ (\mathrm{mGy})\end{array}\end{array}$

\begin{tabular}{|c|c|c|c|c|c|}
\hline $\begin{array}{l}\quad \text { Patiens } \\
\text { with } \\
\text { complete } \\
\text { ablation } \\
\qquad(\mathrm{n}=71)\end{array}$ & $63.1 \pm 35$ & $13.2 \pm 14$ & $29.5 \pm 2$ & $1.01 \pm 1.2$ & $267.7 \pm 46$ \\
\hline $\begin{array}{l}\text { Patiens } \\
\text { without } \\
\text { complete } \\
\text { ablation } \\
\qquad(n=3)\end{array}$ & $46.8 \pm 46$ & $48.9 \pm 13$ & $28.4 \pm 0.8$ & $0.87 \pm 0.6$ & $227.7 \pm 3$ \\
\hline
\end{tabular}

Mann-Whitney $U$ test results showed that there was a significant difference only in the $\mathrm{Tg}$ value between complete ablated and non-ablated patient groups $(\mathrm{z}=-2.7, \mathrm{p}=0.001)$. In terms of other parameter values; TSH $(\mathrm{p}=0.479), \mathrm{Te}(\mathrm{p}=0,827)$, Thyroidal Uptake $(\mathrm{p}=0,796)$, TBAD $(\mathrm{p}=0,857)$

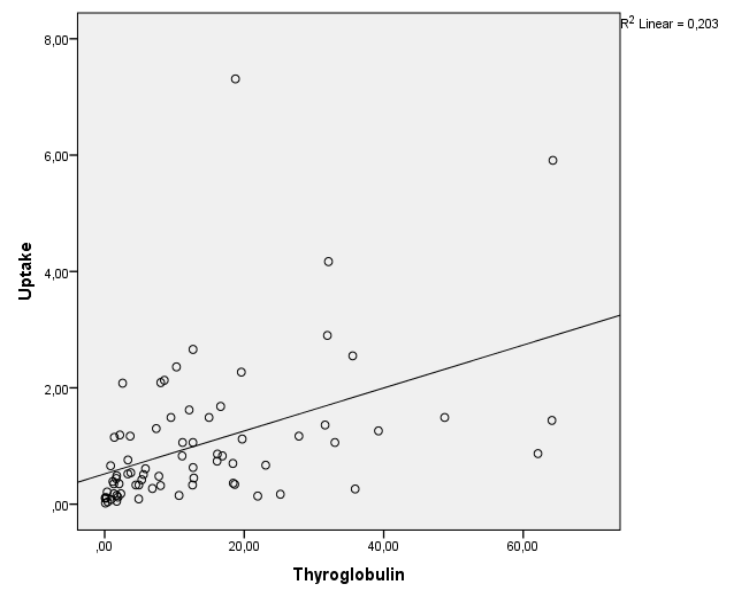

there was no significant difference between the two groups.

In patients, when $\mathrm{Tg}$ values and uptake values were compared with sperman analysis, there was intermediate correlation between them $(r=0.616$, $\mathrm{p}=0.01)$ (Figure 1).

Figure 1. Relationship between thyroglobulin and thyroid uptake.

There was a low correlation in the negative direction between TSH levels and uptake values of patients before ablation ( $\mathrm{r}=-0.218, \mathrm{p}=0.05)$.

The mean total body absorptive dose of the patients was $264.4 \pm 41 \mathrm{mGy}$. There was a low correlation between absorbed doses and $\mathrm{Tg}$ values $(\mathrm{r}=0.212, \mathrm{p}=0.05)$.

\section{DISCUSSION}

Although differentiated thyroid cancer is generally treatable and has good prognosis, life expectancy can be shorten in patients with 
extensive local tumor invasion, lateral lymph node or distant metastases at diagnosis and especially at the age of $\geq 45$ years ${ }^{6}$. Principally a primary treatment is subtotal/ total thyroidectomy and then ablation treatment with I-131 for completely removing the residual tissue is suggested as a routine ${ }^{11}$. In previous studies, it has been reported that, leaving little residual as possible after total thyroidectomy prevents recurrence. It was reported that the residual thyroid lobe in patients who experienced only lobectomy operation, is a potential source of recurrence; whereas, total thyroidectomy was reported to contribute to life expectancy even in the metastatic cases. Additionally, the smaller the residual tissue after subtotal/total thyroidectomy, both improves the efficiency of I-131 therapy and decreases the frequency of radiation thyroiditis which may be seen as a I-131 therapy-related side effect ${ }^{2}$. However it is known that, the success of ablation therapy depends on the thyroid remnant, neoplastic foci and the absorbed dose in metastatic tissues ${ }^{12}$.

Thyroglobulin is a quite sensitive marker which is released only from thyroid follicular cells and predicts recurrence after total thyroidectomy. Therefore, radioiodine ablation treatment is a gold standard treatment choice for an accurate followup after thyroidectomy ${ }^{2}$. Low serum Tg level at the pre-ablation term has negative predictive value for absence of residual disease and the risk of persistent disease increases with stimulated-Tg levels ${ }^{13}$. The present studies were undertaken to evaluate the hypothesis that the ratio of serum $\mathrm{Tg}$ to I-131 uptake in the thyroid bed could be used during postsurgery conditions and before initiating I-131 therapy to detect thyroid cancer (residual or metastatic lesions), even in the presence of remnant thyroid tissue. Grünwald et al. ${ }^{14}$ reported that, Tg/ I-131 uptake ratio might be considered as a prognostic marker. Verkooijen et al. ${ }^{15}$ found that unsuccessful ablation depends on the extent of the thyroid remnant. Whereas in another study, no statistically significant correlation was found between first stimulated-Tg value and percentage of I-131 uptake by residual thyroid tissue ${ }^{16}$. According to our study, an intermediate correlation between stimulated-Tg levels and uptake values were found, which shows that stimulated-Tg levels can be a rather good indicator for the amount of pre-ablation residual tissue estimation. In a study done by McDougall and Bayer ${ }^{17}$, the authors compared the preradioiodine ablation therapy diagnostic dose (with $2 \mathrm{mCi}$ of I-131) whole body scan and simultaneously measured serum $\mathrm{Tg}$ results after the total/near thyroidectomy in differentiated thyroid cancer patients. According to the study, in patient group in whom serum Tg level could not be measured (in whom serum Tg level was <5 $\mathrm{ng} / \mathrm{ml}$ ), WBS were negative in 11 of 12 patients, while residual thyroid tissue was observed in 1 patient. Consequently, in patient group with immeasurable low Tg values, a good correlation was found with WBS results and serum Tg levels. On the other hand, in patient group with serum $\mathrm{Tg}$ levels between 10-45 ng/ml, patients with no I131 uptake were included. In a study that, it has been suggested post-surgery residue tissue quantity is important in success of therapy and the doses applied according to the residue mass of this tissue may be more successful ${ }^{18}$. In parallel with the results of these studies, $\mathrm{Tg}$ values were found to be significantly higher in patiens without complete ablation than those who were with complete ablation in our study.

According to the results found in our patient group, TSH levels before ablation may not predict iodine uptake and success of treatment. Although in literature for sufficient iodine uptake the TSH level is offered to be $\geq 30 \mu \mathrm{U} / \mathrm{ml}$, for higher levels there is no information stating that the ablation rate would be better ${ }^{19}$. For this reason, perhaps no relationship between success of the treatment and TSH level may be associated with an unknown condition. However, high stimulated-Tg levels in our study were effective in the success of treatment.

As a result of studies performed for internal dosimetric calculations and development of MIRD program, doses taken by patients were calculated and studies concentrated on personal dose calculation. Hanscheid et al. ${ }^{20}$ calculated the absorbed dose in blood by using total body counts in the WBS performed at 2nd, 24th, 48th and 72 nd hours' post-radioiodine therapy and counts in obtained blood samples. And they suggested that, by calculation of absorbed dose to the blood per unit of radioactive substances, ${ }^{131}$ I dose could be determined in therapy planning according to the calculation of target blood dose. They also determined that, blood dose exceeded 2 Gy which is blood dose limit of $7.4 \mathrm{GBq}(200 \mathrm{mCi}) \mathrm{I}-131$ dose used empirically in patients with metastases and also suggested that dose quantity could be calculated according to 1,3 Gy maximum target absorbed blood dose. Lassman et al. ${ }^{21}$ stated that making pre-treatment blood dose calculations, particularly in patient groups chosen according to risk groups, could prevent blood dose excess caused by fixed dose application and side-effect severity. However, Verkooijen et al. [22] found 
that, upon comparing the method based on uptake with empiric high dose application, empiric high dose ${ }^{131}$ I application was more effective in the success of ablation. In our study, the mean total body absorptive dose of the patients was $264.4 \pm$ $41 \mathrm{mGy}$. The mean of the patients who were not fully ablated was $227.8 \pm 3 \mathrm{mGy}$ and the mean of the patients who had full ablation was $265 \pm 42$ mGy. But there was no significant difference in the TBAD between the two groups.

As a result, we observed that the $\mathrm{Tg}$ values measured before radioiodine treatment informed the remaining tissue after surgery and that the residual tissue size could affect the treatment efficacy. For this reason, more careful follow-up in the patient group with high pretreatment $\mathrm{Tg}$ values will be beneficial.

\section{REFERENCES}

1- Lind P, Igerc I, Kohlfürst S. Radioiodine Theraph.: Malignant Thyroid Disease. Biersack H, Freeman L, Zuckier LS, Grünwald $F$ eds. Clinical Nuclear Medicine. $1^{\text {st }}$ ed. Springer-Verlag Berlin Heidelberg; 2007. p. 418-32.

2- Mazzaferri EL, Kloos RT, Clinical Review, Current Approaches to Primary Therapy For Papillary And Follicular Thyroid Cancer. The Journal of Clin. Endocrinol \& Metabolism, 2001; 86 (4):1447-63.

3- Brassard M, Borget I, Edet-Sanson A, Giraudet AL, Mundler O, Toubeau M, Bonichon F, Borson-Chazot F, Leenhardt L, Schvartz C, Dejax C, Brenot-Rossi I, Toubert ME, Torlontano M, Benhamou E, Schlumberger M. Long-Term Follow-Up of Patients with Papillary and Follicular Thyroid Cancer: A Prospective Study on 715 Patients, J Clin Endocrinol Metab, 2011; 96:1352-9.

4- Mazzaferri EL, Robbins RJ, Spencer CA, Braverman LE, Pacini F, Wartofsky L, Haugen BR, Sherman SI, Cooper DS, Braunstein GD, Lee S, Davies TF, Arafah BM, Ladenson PW, Pinchera A. A Consensus report of the role of serum thyroglobulin as a monitoring method for low-risk patients with papillary thyroid carcinoma. J Clin. Endocrinol Metab, 2003; 88: 433-41.

5- Grande E, Díez JJ, Zafon C, Capdevila J. Thyroid cancer: molecular aspects and new therapeutic strategies. J Thyroid Res. 2012; 2102:847108.
6- Verburg FA, Mäder U, Tanase K, Thies ED, Diessl S, Buck AK, Luster M, Reiners C. Life Expectancy Is Reduced in Differentiated Thyroid Cancer Patients $\geq 45$ Years Old with Extensive Local Tumor Invasion, Lateral Lymph Node, or Distant Metastases at Diagnosis and Normal in All Other DTC Patients. J Clin Endocrinol Metab, 2013; 98:172-80.

7- Bales SR, Chopra IJ. Targeted treatment of differentiated and medullary thyroid cancer. $\mathrm{J}$ Thyroid Res, 2011; 2011:102636.

8- Dobrenic M, Huic D, Zuvic M, Grosev D, Petrovic R, Samardzic T. Usefulness of low iodine diet in managing patients with differentiated thyroid cancer-initial results. Radiol Oncol, 2011; 45:189-95.

9- Fatima N, Zaman M, Ikram M, Akhtar J, Islam N, Masood Q, Zaman U, Zaman A. Baseline stimulated thyroglobulin level as a good predictor of successful ablation after adjuvant radioiodine treatment for differentiated thyroid cancers. Asian Pac J Cancer Prev, 2014; 15: 6443-47.

10- Shahbazi-Gahrouei D, Ayat S. Comparison of three methods of calculation, experimental and monte carlo simulation in investigation of organ doses (thyroid, sternum, cervical vertebra) in radioiodine therapy. J Med Signals Sens, 2012; 2: 149-52.

11- Ogilvie JB, Patel KN, Heller KS. Impact of the 2009 American Thyroid Association Guidelines on the choice of operation for welldifferentiated thyroid microcarcinomas. Surgery, 2010; 148:1222-6.

12- Flux GD, Haq M, Chittenden SJ, Buckley S, Hindorf C, Newbold K, Harmer CL. A doseeffect correlation for radioiodine ablation in differentiated thyroid cancer. Eur J Nucl Med Mol Imaging, 2010; 37: 270-5.

13- Pacini F, Capezzone M, Elisei R, Ceccarelli C, Taddei D, Pinchera A. Diagnostic 131iodine whole-body scan may be avoided in thyroid cancer patients who have undetectable stimulated serum $\mathrm{Tg}$ levels after initial treatment. J Clin Endocrinol Metab, 2002; 87: 1499-501.

14- Grünwald F, Menzel C, Fimmers R, Zamora PO, Biersack HJ. Prognostic value of thyroglobulin after thyroidectomy before ablative radioiodine therapy in thyroid cancer. J Nucl Med, 1996; 37:1962-4. 
15- Verkooijen RB, Stokkel MP, Smit JW, Pauwels EK. Radioiodine-131 in differentiated thyroid cancer: a retrospective analysis of an uptake-related ablation strategy. Eur $\mathrm{J}$ Nucl Med Mol Imaging, 2004; 31: 499-506.

16- Ronga G, Filesi M, Ventroni G, Vestri AR, Signore A. Value of the first serum thyroglobulin level after total thyroidectomy for the diagnosis of metastases from differentiated thyroid carcinoma. Eur J Nucl Med, 1999; 26:1448-52.

17- Mcdougall IR, Bayer MF. Follow-Up of patients with differentiated thyroid cancer using serum thyroglobulin measured by an immunoradiometric assay. Comparison with 131I total body scans. J Nucl Med, 1980; 21: 741-44.

18- Samuel AM, Rajashekharrao B. Radioiodine therapy for well-differentiated thyroid cancer: a quantitative dosimetric evaluation for remnant thyroid ablation after surgery. J Nucl Med, 1994; 35:1944-50.
19- Amdur JA, Mazzaferri EL. Thyroid Hormone Withdrawal to Elevate TSH. In 'Essentials of Thyroid Cancer Management' AmdurJA, Mazzaferri EL (Ed). Springer Science+Business Media, 2005; pp: 229-31.

20- Hänscheid H, Lassmann M, Luster M, Kloos RT, Reiners C. Blood dosimetry from a single measurement of the whole body radioiodine retention in patients with differentiated thyroid carcinoma. Endocr Relat Cancer. 2009; 16(4): 1283-9.

21- Lassmann M, Reiners C, LusterM. Dosimetry and thyroid cancer: the individual dosage of radioiodine. Endocr Relat Cancer. 2010;17(3):161-72.

22- Verkooijen RB, Verburg FA, van Isselt JW, Lips CJ, Smit JW, Stokkel MP. The success rate of I-131 ablation in differentiated thyroid cancer: comparison of uptake-related and fixed-dose strategies. Eur J Endocrinol. 2008; 159(3): 301-7. 